\title{
A Comparative Study Of Surgical Outcome In Different Approaches For Hysterectomy
}

\author{
Tamrakar SR
}

\begin{abstract}
Introduction: -Globally, hysterectomy has been the commonest gynecologic surgery since a long time. One of the most remarkable innovations in surgery has been the changeover from laparotomy to laparoscopy. The first reported laparoscopic hysterectomy was in 1989 by Harry Reich, for endometriosis. As laparoscopic procedure has various important advantages over laparotomy, it has become a preferred surgical method. But open hysterectomy or laparoscopic hysterectomy has been chosen based on various factors and the surgeon's experience and skill. Earlier hysterectomies were done in conventional way at Kathmandu University Hospital. But Laparoscopic assisted vaginal hysterectomy and total laparoscopic hysterectomy were started from 2011 and 2015 respectively. Method: This retrospective study was undertaken to compare the demographic parameters, operative particulars, postoperative outcomes including complications of different hysterectomy approaches done from 2011 to 2018 at Kathmandu University Hospital. Result:A total of 756 hysterectomy cases with 461 of open hysterectomy and 295 of laparoscopic hysterectomy were done in over 8 years. There was no significant difference in mean age of patients who underwent different types of hysterectomies ( $46.29 \pm 6.50$ and $45.52 \pm 8.15$ years, $p=0.6829)$. There was significant increase in Brahmin/Chhetri caste seeking laparoscopic hysterectomy $(p=0.0001)$ and significant decrease in other janajati caste undergoing laparoscopic hysterectomy ( $p=0.0004)$. The indications of different type of hysterectomy were almost comparable; with fibroids/adenomyosis (49.7\%) followed by abnormal uterine bleeding (19.7\%) were common indications. Laparoscopic hysterectomies have significantly increased since 2016. There were significant differences in operating time, blood loss and hospital stay between open and laparoscopic hysterectomy cases with $143.63 \pm 43.25$ vs $67.56 \pm 25.75$ minutes, $294.78 \pm 51.37$ vs $470.24 \pm 102.99 \mathrm{ml}$ and $2.61 \pm 0.66$ vs $5.64 \pm 0.69$ days respectively (all $p<0.0001$ ). There were 30 major complications in open and 10 in laparoscopic hysterectomy respectively with 9 minor complications in both. Eleven laparoscopy cases (3.7\%) had to be converted to laparotomy. Conclusions: Laparoscopic hysterectomies are possible with equivalent advantages. A good laparoscopic experiences for surgeons and a careful selection of the cases are the obligatory prerequisites.
\end{abstract}

Keywords: Conversion, Fibroids, Hysterectomy, Laparoscopy Hysterectomy (LH), Laparoscopy Assisted Vaginal Hysterectomy(LAVH), Total Abdominal Hysterectomy(TAH)

\section{INTRODUCTION}

Globally, hysterectomy has been the commonest gynecologic surgery worldwide since long time ${ }^{1}$. The aspiration for minimal invasive surgery and the capacity of surgeons to update surgical skills has contributed to the significant recent developments in laparoscopic surgery².

One of the most remarkable innovations in surgery has been the changeover from laparotomy to laparoscopy. The first

1. Dr. Suman Raj Tamrakar

\section{Address for correspondence:}

Dr. Suman Raj Tamrakar

Associate Professor

Department of Obstetrics and Gynecology

Dhulikhel Hospital, Kathamandu University of School Medical

Sciences, Dhulikhel

e-mail: drsuman3947@gmail.com reported laparoscopic hysterectomy was in 1989 by Harry Reich, for endometriosis. Since then, laparocopic hysterectomy has been considered as an alternative to abdominal hysterectomy ${ }^{3}$. Laparoscopic procedure have various important advantages over laparotomy, hence it has become preferred surgical method ${ }^{4,5}$.

Total abdominal hysterectomy (TAH) or laparoscopic hysterectomy has been chosen based on various factors and the surgeon's experience and skill. However, laparoscopic hysterectomy has a longer learning curve, takes longer to perform and has been known to have a higher complication rate than abdominal hysterectomy, particularly in initial period $^{6}$.

In Dhulikhel Hospital (DH), also known as Kathmandu University Hospital (KUH), gynecological surgeries including hysterectomies are being regularly done in conventional way till 2011. Laparoscopic assisted vaginal hysterectomy (LAVH) service started and regularly being performed since February 2011. Later total laparoscopic hysterectomy (TLH) service was 
started from June 2015.

Though, there are ample of comparative studies done in the field of hysterectomy approaches, only limited publications related to experiences of gynecological minimal invasive surgeries available from Nepal ${ }^{7-10}$. Earlier, there is no such comparative study done in $\mathrm{KUH}$. This retrospective study aimed to compare the operative data and postoperative outcomes and complications of different hysterectomy approaches (TAH versus LAVH or TLH) for benign gynecological conditions in women at $\mathrm{KUH}$.

\section{METHOD}

This retrospective (comparative) study of the different hysterectomy approaches (TAH vs LAVH or TLH) done in women who underwent these surgeries between 2011 and 2018 in DH. This study was carried out in Department of Obstetrics and Gynaecology reviewing all the OPD/inpatient and Operation Theater (OT) records (including electronic).

For analysis purpose, TAH and staging laparotomy were considered as open hysterectomy $(\mathrm{OH})$ and LAVH and TLH were considered as laparoscopic hysterectomy (LH) in the study.

Ethical clearance was taken from the hospital research committee (IRC-KUSMS\#39/19). All data were entered in excel sheet and analyzed by SPSS 16 packages using appropriate statistical tools like frequency, percentage, means, $p$ value, Chi square test.

\section{RESULTS}

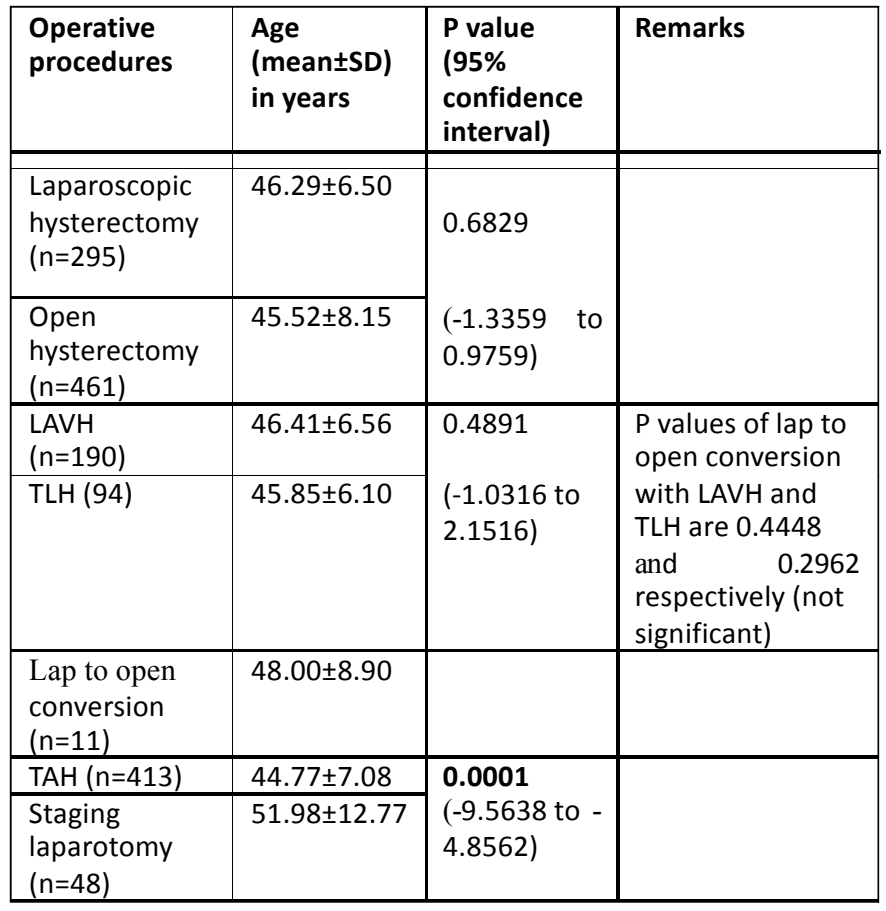

Table I: Mean ages of different hysterectomy cases
There was no significant difference in mean ages of different groups except that between $\mathrm{TAH}$ and staging laparotomy group (Table I).

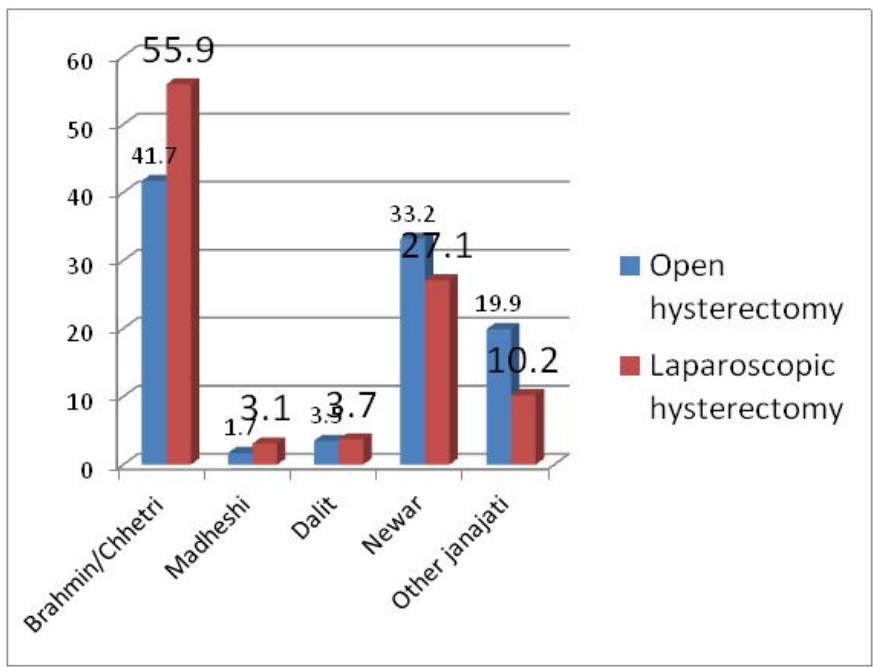

Figure 1: Caste distribution of hysterectomy cases (open and laparoscopic)

There was significant increase in Brahmin/Chhetri caste seeking laparoscopic hysterectomy $(p=0.0001)$ and significant decrease in other janajati caste undergoing laparoscopic hysterectomy $(p=0.0004)$. There is not much difference in patients coming for open or laparoscopic hysterectomy from different parts of Nepal. Patients undergoing laparoscopic hysterectomy or open hysterectomy from Kavre, neighbouring districts (Sindhupalchowk Dolakha Ramechhap Sindhuli), Kathmandu valley and other districts were 144 (48.8\%) and $242(52.5 \%), 36(12.2 \%)$ and $66(14.3 \%), 87(29.5 \%)$ and $124(26.9 \%) ; 28(9.5 \%)$ and $29(6.3 \%)$ respectively.

\begin{tabular}{|c|c|c|c|c|}
\hline Indication & Operation & Present & Absent & $P$ value \\
\hline \multirow[t]{2}{*}{$\begin{array}{l}\text { Fibroids/ } \\
\text { Adenomyosis }\end{array}$} & $\begin{array}{l}\text { Laparoscopic } \\
\text { hysterectomy } \\
(\mathrm{n}=295)\end{array}$ & 137 & 158 & \multirow{2}{*}{$\begin{array}{l}0.1472 \\
\text { (not } \\
\text { significant) }\end{array}$} \\
\hline & $\begin{array}{l}\text { Open } \\
\text { hysterectomy } \\
(\mathrm{n}=461)\end{array}$ & 239 & 222 & \\
\hline \multirow{2}{*}{$\begin{array}{l}\text { Abnormal } \\
\text { Uterine } \\
\text { Bleeding } \\
\text { (AUB ) }\end{array}$} & $\begin{array}{l}\text { Laparoscopic } \\
\text { hysterectomy } \\
(\mathrm{n}=295)\end{array}$ & 79 & 216 & \multirow{2}{*}{$<0.0001$} \\
\hline & $\begin{array}{l}\text { Open } \\
\text { hysterectomy } \\
(\mathrm{n}=461)\end{array}$ & 70 & 391 & \\
\hline \multirow[t]{2}{*}{$\begin{array}{l}\text { Ovarian } \\
\text { lesions }\end{array}$} & $\begin{array}{l}\text { Laparoscopic } \\
\text { hysterectomy } \\
(n=295)\end{array}$ & 13 & 272 & \multirow[t]{2}{*}{$<0.0001$} \\
\hline & $\begin{array}{l}\text { Open } \\
\text { hysterectomy } \\
(\mathrm{n}=461)\end{array}$ & 93 & 369 & \\
\hline $\begin{array}{l}\text { Cervical } \\
\text { lesions }\end{array}$ & $\begin{array}{l}\text { Laparoscopic } \\
\text { hysterectomy } \\
\text { (n=295) }\end{array}$ & 31 & 264 & $\begin{array}{l}0.0644 \\
\text { (not }\end{array}$ \\
\hline
\end{tabular}




\begin{tabular}{|c|c|c|c|c|}
\hline & $\begin{array}{l}\text { Open } \\
\text { hysterectomy } \\
(n=461)\end{array}$ & 31 & 430 & significant) \\
\hline \multirow[t]{2}{*}{$\begin{array}{l}\text { Chronic } \\
\text { pelvic pain/ } \\
\text { Endometriosis }\end{array}$} & $\begin{array}{l}\text { Laparoscopic } \\
\text { hysterectomy } \\
(n=295)\end{array}$ & 17 & 278 & \multirow[t]{2}{*}{0.0165} \\
\hline & $\begin{array}{l}\text { Open } \\
\text { hysterectomy } \\
(n=461)\end{array}$ & 11 & 450 & \\
\hline \multirow[t]{2}{*}{$\begin{array}{l}\text { Polyp } \\
\text { (cervical/endo } \\
\text { metrial) }\end{array}$} & $\begin{array}{l}\text { Laparoscopic } \\
\text { hysterectomy } \\
(n=295)\end{array}$ & 10 & 285 & \multirow{2}{*}{$\begin{array}{l}0.1455 \\
\text { (not } \\
\text { significant) }\end{array}$} \\
\hline & $\begin{array}{l}\text { Open } \\
\text { hysterectomy } \\
(n=461)\end{array}$ & 8 & 453 & \\
\hline \multirow[t]{2}{*}{ Miscellaneous } & $\begin{array}{l}\text { Laparoscopic } \\
\text { hysterectomy } \\
(n=295)\end{array}$ & 8 & 287 & \multirow{2}{*}{$\begin{array}{l}0.4920 \\
\text { (not } \\
\text { significant) }\end{array}$} \\
\hline & $\begin{array}{l}\text { Open } \\
\text { hysterectomy } \\
(n=461)\end{array}$ & 9 & 452 & \\
\hline
\end{tabular}

Table II: Indications of hysterectomy (open and laparoscopic)

The indications of different type of hysterectomy were almost comparable (Table II). But there was significant difference in operation (OT) duration, blood loss and hospital stays between those underwent open and laparoscopic hysterectomy (Table III).

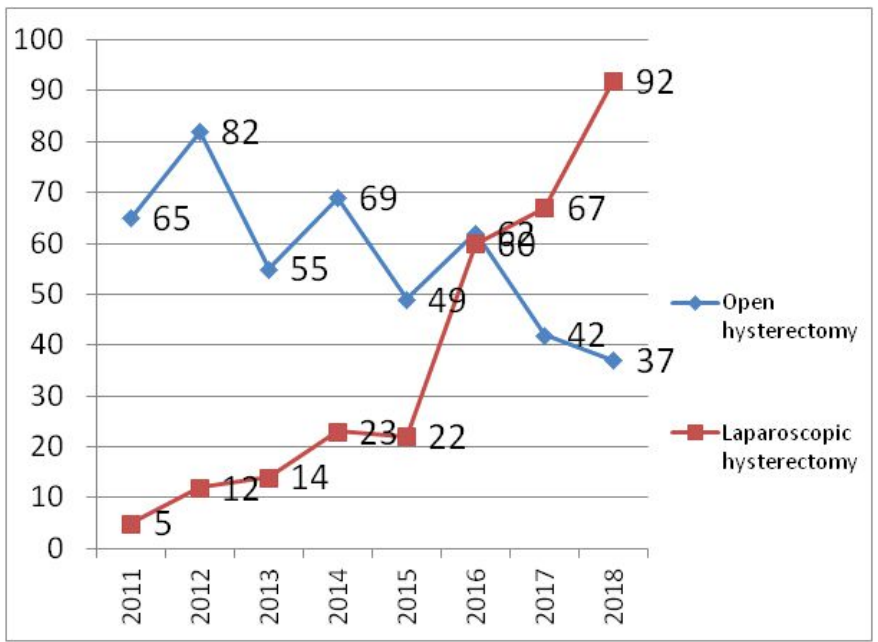

Figure 2: Trend of hysterectomy cases (open and laparoscopic)

Laparoscopic hysterectomy cases were gradually going up in comparison to open hysterectomy cases, significantly from 2016 (Figure 2). Different complications (major and minor) and laparoscopy conversion to laparotomy showed in Table IV.

\begin{tabular}{|c|c|c|}
\hline Operative procedures & $\begin{array}{l}\text { OT duration } \\
\text { (mean } \pm S D) \text { in } \\
\text { minutes }\end{array}$ & $\begin{array}{l}\text { P value } \\
\text { ( } 95 \% \\
\text { confidence } \\
\text { interval) }\end{array}$ \\
\hline $\begin{array}{l}\text { La paroscopic } \\
\text { hysterectomy }(n=295)\end{array}$ & $143.63 \pm 43.25$ & \multirow{2}{*}{$\begin{array}{l}<0.0001 \\
(-81.0027 \text { to }- \\
71.1373)\end{array}$} \\
\hline \multirow[t]{2}{*}{$\begin{array}{l}\text { Open hysterectomy } \\
(n=461)\end{array}$} & $67.56 \pm 25.75$ & \\
\hline & $\begin{array}{l}\text { Blood loss } \\
\text { (mean } \pm S D) \text { in } \mathrm{ml}\end{array}$ & \\
\hline $\begin{array}{l}\text { Laparoscopic } \\
\text { hysterectomy }(n=295)\end{array}$ & $294.78 \pm 51.37$ & \multirow{3}{*}{$\begin{array}{l}<0.0001 \\
(162.7738 \text { to } \\
188.1462)\end{array}$} \\
\hline Open hysterectomy & $470.24 \pm 102.99$ & \\
\hline & $\begin{array}{l}\text { Hospital stay } \\
\text { (mean } \pm S D) \text { in } \\
\text { days }\end{array}$ & \\
\hline $\begin{array}{l}\text { Laparoscopic } \\
\text { hysterectomy }(n=295)\end{array}$ & $2.61 \pm 0.66$ & \multirow{2}{*}{$\begin{array}{l}<0.0001 \\
(2.9306 \text { to } \\
3.1294)\end{array}$} \\
\hline $\begin{array}{l}\text { Open hysterectomy } \\
(n=461)\end{array}$ & $5.64 \pm 0.69$ & \\
\hline
\end{tabular}

Table III: Differences in OT duration, blood loss and hospital stays

\begin{tabular}{|l|l|l|}
\hline Complications & $\begin{array}{l}\text { Open } \\
\text { hysterectomy } \\
\text { (n=461) }\end{array}$ & $\begin{array}{l}\text { Laparoscopic } \\
\text { hysterectomy } \\
\text { (n=295) }\end{array}$ \\
\hline Major & 1 & - \\
\hline Bladder injury & 1 & 2 \\
Ureteral injury & 2 & - \\
Bowel injury & - & 1 \\
Vesicovaginal fistula & - & - \\
Major vessel injury & - & - \\
Vaginal cuff dehiscence & 3 & - \\
Burst abdomen & 23 (maximum & 7 (maxim um \\
Blood transfusion & 3 pints) & 2 pints) \\
\hline \multicolumn{2}{|l|}{} \\
\hline Minor & 2 & 3 \\
\hline Vault bleeding & 7 & - \\
Wound infection & - & 3 \\
Trocar hernia & - & 3 \\
Cautry burn & - & 11 \\
Subcuteneous haematoma & & \\
\hline Total complication & 39 & - \\
\hline Number of conversion to & - & \\
laparotomy & & \\
\hline
\end{tabular}

Table IV: Complications occurred during hysterectomy

\section{DISCUSSION}

One of the most remarkable innovations in surgery has been the changeover from laparotomy to laparoscopy. The first reported laparoscopic hysterectomy was in 1989 by Harry Reich, for endometriosis. Since then, laparoscopic hysterectomy has been considered as an alternative to abdominal hysterectomy ${ }^{3}$. The aspiration for minimal invasive 
surgery and the capacity of surgeons to update surgical skills has contributed to the significant recent developments in laparoscopic surgery ${ }^{2}$.

Beside mean age, caste and address of the patients (Table I and Figure 1), indications of different hysterectomy in $\mathrm{DH}$ are almost comparable (Table II) except that of Brahmin/Chhetri and other janajati caste; and AUB and ovarian lesions.

In this study, mean age of the patients underwent $\mathrm{OH}$ and $\mathrm{LH}$ were $45.52 \pm 8.15$ and $46.29 \pm 6.5$ years respectively (Table I). This was almost similar to study finding of Naveiro $\mathrm{M}$, et $\mathrm{al}^{11}$, in which mean age was $45.2 \pm 5.7$ years (first $75 \mathrm{LH}$ ), $48.3 \pm 10.2$ years (second $75 \mathrm{LH}$ ) and $50.8 \pm 11.7$ years (third $86 \mathrm{LH}$ ). And, in a study by Song T, et a ${ }^{12}(n=100)$ of single-port access (SPA)-LAVH , the mean age of the patients was $45.8 \pm 5.1$ years. But the mean age was comparatively high in studies by Terzi $\mathrm{H}$, et $\mathrm{al}^{13}$ and Pather $\mathrm{S}$, et al ${ }^{14}$ with $48.9 \pm 5.9$ years; and $59.1(\mathrm{OH})$ and 56.2 (LH) respectively.

The most common indications of hysterectomy were fibroid/adenomyosis followed by $A \cup B^{15}$. This was similar to study by Harkki Siren $P$, et $\mathrm{al}^{16}$ in which indications for laparoscopic hysterectomy were uterine fibroids (64\%) and menorrhagia (20\%). Kim SM, et $\mathrm{al}^{2}$ showed the indications of TAH and multi-port access (MPA)-TLH were myoma 162 (57\%) and $224(61.2 \%)$ followed by adenomyosis 61 (21.5\%) and 55 (15\%) respectively. Additional 40(14.1\%) and 49(13.4\%) were myoma with adenomyosis.

In a study by Song $\mathrm{T}$, et $\mathrm{al}^{12}$, pathologic diagnoses at hysterectomy included myoma (48\%), myoma combined with adenomyosis $(23 \%)$, adenomyosis (21\%), endometrial hyperplasia (4\%), and cervical carcinoma in situ (3\%), and chronic pelvic pain combined with endometriosis (1\%).Likewise Terzi $\mathrm{H}$, et $\mathrm{al}^{13}$ shared the indications TLH were AUB 89 (34.6\%), myoma uteri 65(25.3\%) and AUB and myomauteri $48(18.7 \%)$.

Indications of hysterectomy were also similar in this study. Fibroids $46.4 \%$ and $51.8 \%$ followed by AUB $26.8 \%$ and $15.2 \%$ in $\mathrm{LH}$ and $\mathrm{OH}$ respectively (Table $\mathrm{II})$. Terzi $\mathrm{H}$, et $\mathrm{al}^{13}$ showed prolpsus uteri $4(1.6 \%)$ was the one of the indications. In our study five $\mathrm{LH}$ and one $\mathrm{OH}$ were done for prolapsed uterus. Likwise Kim SM, et al ${ }^{2}$ showed CIN 2,3 were indications for TAH and MPA-TLH were 11 (3.9\%) and $16(4.4 \%)$ respectively. In this study $13 \mathrm{LH}$ and $20 \mathrm{OH}$ were done for $\mathrm{CIN2}, 3$ and beyond.

Average operation duration of $\mathrm{OH}$ and $\mathrm{LH}$ were $67.56 \pm 25.75$ minutes and $143.63 \pm 43.25$ years respectively in this study (Table III). This was similar to study finding of Agarwal P, et al ${ }^{15}$ and exactly same to study finding of Garett AJ, et $\mathrm{al}^{17}$. The average time required in TLH in the first year after starting surgery was $147.37 \mathrm{~min}$ compared to $84.84 \mathrm{~min}$ in $\mathrm{TAH}^{15}$. Mean operating time was $143.1 \pm 40.4$ minutes $^{17}$. The operating time was shorter in the studies by Terzi $\mathrm{H}$, et $\mathrm{al}^{13}$, Harkki Siren $\mathrm{P}$, et al ${ }^{16}$ and Song $\mathrm{T}$, et $\mathrm{al}^{12}$ with $70.4 \pm 15.4$ minutes, $109 \pm 45$ minutes and $115.7 \pm 40.3$ minutes respectively. And the operation time was longer in the studies by Kim SM, et al ${ }^{2}$ and Pather S, et $\mathrm{al}^{14}$. Total operative time was $176.4 \pm 47.9$ minutes in TAH and $149.3 \pm 59.5$ minutes in MPA-TLH ${ }^{2}$. Mean operation time was 226 minutes in first $25 \mathrm{TLH}$ cases, 200 minutes in last $25 \mathrm{TLH}$ cases and 175.5 minutes in $\mathrm{OH}^{14}$.

Average intraoperative blood loss was significantly lower in TLH as opposed to TAH. Amout of blood loss was $411.82 \pm 70.10 \mathrm{ml}$ (TAH) and $145.12 \pm 29.51 \mathrm{ml}(\mathrm{TLH})^{15}$. Kim SM, et al ${ }^{2}$ found the estimated blood loss $427.1 \pm 250.6 \mathrm{ml}$ in TAH and $163.8 \pm 168.9$ $\mathrm{ml}$ in MPA-TLH. In this study average blood loss was $470.24 \pm 102.99 \mathrm{ml}(\mathrm{OH})$ and $294.78 \pm 51.37 \mathrm{ml}$ (LH) (Table III). Mean estimated blood loss was $307.6 \pm 246.3 \mathrm{ml}^{17}$. That was 250-215 $\mathrm{ml}^{16}$.

While we prefer laparoscopic to conventional (open) gynecological surgeries, we are anxious about its complications. In this study the conversion to laparotomy was $3.7 \%$ (11 out of 295 LH cases) (Table IV). The reasons for conversion were big myoma (6), dermoid cysts (2), grade IV endometriosis (2) and adenomyosis (1).

Conversion to an open laparotomy was needed in one percent ${ }^{12}$. Total conversion rate was $2.9 \%{ }^{18}$. Seventeen cases from the MPA-TLH group $(n=366)$ required unplanned intraoperative laparotomy conversion ${ }^{2}$.Total rate of conversion to laparotomy was $9.6 \%$ (12 out

of 125$)^{15}$. Eight of 120 patients (6.6\%) required conversion to laparotomy ${ }^{17}$. Conversion to laparotomy was $9(12.0 \%)$ in first $75 \mathrm{LH}, 9(12.0 \%)$ in second $75 \mathrm{LH}$ and $1(1 \%)$ in third $86 \mathrm{LH}$, showing gradual decrease in conversion rate ${ }^{11}$. Conversion to laparotomy generally occurred more frequently in the early learning phase ${ }^{19}$.

In the literature, the rates varied for conversion from laparoscopy to laparotomy, from $6.6 \%$ to $0.03 \% \%^{17,19-21}$. The complications were related to advanced disease and broad adhesions rather than due to laparoscopy, itself. Our rate of conversion to laparotomy was $1.9 \%{ }^{13}$.

In this study average duration of hospital stay was $5.64 \pm 0.69$ days and $2.61 \pm 0.66$ days in $\mathrm{OH}$ and $\mathrm{LH}$ group respectively (Table III). The average durations of hospital stay in TAH group were $5.68 \pm 3.10$ days and $3.58 \pm 1.97$ days in $\mathrm{TLH}^{15}$.

The mean hospital stay was $1.3 \pm 0.5$ days $^{16}$. That was $2.4 \pm 1.4$ days (entire TLH group) ${ }^{17}$. Naveiro $M$, et al ${ }^{11}$ shared their hospital stay findings with $4.0 \pm 3.1$ days, $2.9 \pm 1.2$ days and $2.5 \pm 1.6$ days in first $75 \mathrm{LH}$, second $75 \mathrm{LH}$ and third $86 \mathrm{LH}$ respectively. Kim SM, et al ${ }^{2}$ found hospital stay $7.0 \pm 2.1$ days in 
TAH and 5.5 \pm 2.0 days in MPA-TLH group.

Mean length of stay was 2.62 days in first 25 TLH cases, 1.82 days in last $25 \mathrm{TLH}$ cases and 3.38 days in $\mathrm{OH}^{14}$. The median postoperative hospital stay was 3 days (range $3-7$ days) ${ }^{12}$. And stay in hospital was $3.4 \pm 1.2$ days $^{13}$.

The total complication rate was $6.2 \%$. Complications were classified as major (3.1\%) and minor $(3.1 \%)^{13}$. Driessen S, et $\mathrm{al}^{18}$ experienced complications of $4.7 \%$. Incidence of major complications in TLH was $1.6 \%$ (2 in 125) compared to $4 \%$ (5 in 125 ) in TAH group. Incidence of minor complications in TLH group was $7.1 \%$ (9 out of 125) compared to $9.7 \%$ in TAH group (12 out of 125). Incidence was $14 \%$ (3 out of 22) in the first year $^{15}$. Kim SM, et al $^{2}$ faced overall 15 complications (5.3\%) in TAH compared to 32(8.7\%) in MPA-TLH group. Kim

We experienced 39(8.5\%) complications in $\mathrm{OH}$ and $19(6.4 \%)$ in LH group (Table IV). Naveiro $M$, et al ${ }^{11}$ found overall complications 18 (24\%) in first $75 \mathrm{LH}, 7$ (9.3\%) in second $75 \mathrm{LH}$ and $7(8.1 \%)$ in third $86 \mathrm{LH}$ cases.

Terzi $\mathrm{H}$, et al $^{13}$ showed the need for blood transfusion in 11 (4.3\%). We found blood transfusion in $23(5.0 \%)$ in $\mathrm{OH}$ and 7 (2.4\%) in LH group.

\section{CONCLUSION}

We compared the postoperative outcomes and complications of different hysterectomy approaches in the field of gynaecological surgeries.Laparoscopic hysterectomies are possible with equivalent advantages while managing gynecological lesions as well. Thorough laparoscopic experiences of surgeons and careful selection of the cases are the obligatory prerequisites.

\section{CONFLICTS OF INTEREST}

Author declares that there is no financial support or relationships that may pose potential conflicts of interest.

\section{REFERENCES}

1. Lepine LA, Hillis SD, Marchbanks PA, Koonin LM, Morrow B,Kieke BA et al (1997) Hysterectomy surveillance-United States,1980-1993. MMWR CDC Surveill Summ 46:1-15.

2. Kim SM, Park EK, Jeung IC, Kim CJ, Lee YS. Abdominal, multi-port and single-port total laparoscopic hysterectomy: eleven-year trends comparison of surgical outcomes complications of 936 cases. Arch Gynecol Obstet. 2015 Jun;291(6):1313-9. doi: 10.1007/s00404014-3576-y.

3. Reich H, Caprio JD, Mclynn F. Laparoscopic hysterectomy. J Gynecol Surgery. 1989;5(2):213-6.
4. Pelosi MA. Laparoscopic hysterectomy with bilateral salpingo-oophorectomy using a single umbilical puncture. N J Med. 1991:88:721-6.

5. Johnson N, Barlow D, Lethaby A, Tavender E, Curr L, Garry R. Methods of hysterectomy: systematic review and metaanalysis of randomised controlled trials. BMJ 2005:330:1478.

6. Mäkinen J, Johansson J, Tomás C, Tomás E, Heinonen PK, Laatikainen T et al. Morbidity of 10110 hysterectomies by type of approach. Hum Reprod. 2001:16:1473-8.

7. Padhye SM. Experience of laparoscopic sterilization under local anesthesia in camps in Nepal. J Inst Med. 1984;(6):316.

8. Saha R, Shrestha NS, Thapa M, Shrestha J, Bajracharya J, Karki SC. Experiences of gynecological laparoscopic surgeries in a teaching hospital. J Nepal Health Res Counc. 2013;11(23);49-52.

9. Sharma J, Tiwari S. Hysteroscopy in Abnormal Uterine Bleeding vs Ultrasonography and Histopathology Report in Perimenopausal and Postmenopausal Women. J Nepal Med Assoc. 2016;55(203):26-8.

10. Bajracharya N, Dangal G, Karki A, Pradhan H, Shrestha R, Bhattachan K, Poudel R. Experience of Laparoscopic Gynecological Surgeries at Kathmandu Model Hospital. NJOG. 2017 Jan-Jun; 23 (1):22-5.

11. Naveiro-Fuentes $M$, et al. Effect of surgeon's experience on complications from laparoscopic hysterectomy. J Gynecol Obstet $\mathrm{Hum}$ Reprod. 2017. https://doi.org/10.1016/j.jogoh.2017.11.004

12. Song T, Kim TJ, Lee YY, Choi CH, Lee JW, Kim BG. et al. What is the learning curve for single-port access laparoscopicassisted vaginal hysterectomy? Eur J Obstet Gynecol R e prod B i o I. $2011 ; 158: 93-6$. doi:10.1016/j.ejogrb.2011.04.017

13. Terzi H, Biler A, Demirtas O, Guler OT, Peker N, Kale A. Total laparoscopic hysterectomy: Analysis of the surgical learning curve in benign conditions. Int J Surg. 2016 Nov;35:51-7. doi: 10.1016/j.ijsu.2016.09.010. Epub 2016 Sep 12

14. Pather S, Loadsman JA, Mansfield C, Rao A, Arora V, Philp S, et al. Perioperative outcomes after total laparoscopic hysterectomy compared with fast-track open hysterectomy - A retrospective case-control study. Aust N Z J Obstet Gynaecol. 2011; 51: 393-6. DOI: 10.1111/j.1479-828X.2011.01340.x

15. Agarwal P, Bindal N, Yadav R. Risks and Benefits of Total Laparoscopic Hysterectomy and the Effect of Learning Curve on Them. J Obstet Gynaecol India. 2016 
Oct;66(5):379-84. doi: 10.1007/s13224-015-0706-9. Epub 2015 Jun 11

16. Harkki-Siren P, Sjoberg J, Makinen J et al. Finnish national register of laparoscopic hysterectomies: A review and complications of 1165 operations. Am J Obstet Gynecol 1997;176:118-122.

17. Garrett AJ, Nascimento MC, Nicklin JL, Perrin LC, Obermair A. Total laparoscopic hysterectomy: the Brisbane learning curve. Aust N Z J Obstet Gynaecol. 2007 Feb;47(1):65-9. doi: 10.1111/j.1479-828X.2006.00682.x.

18. Driessen SRC, Wallwiener M, Taran FA, Cohen SL, Kraemer $B$, Wallwiener $C W$, et al. Hospital versus individual surgeon's performance in laparoscopic hysterectomy. Arch Gynecol Obstet. 2017;295:111-7. DOI 10.1007/s00404016-4199-2

19. Ikhena S, Oni M, Naftalin N, Konje J. The effect of the learning curve on the duration and peri-operative complications of laparoscopically assisted vaginal hysterectomy, Acta Obstet. Gynecol. Scand. 1999;78:6325.

20. Donnez O, Jadoul P, Squifflet J, Donnez J. A series of 3190 laparoscopic hysterectomies for benign disease from 1990 to 2006: evaluation of complications compared with vaginal and abdominal procedures. BJOG. 2009;116:492500.

21. Kolkman W, Engels LE, Smeets MJ, Jansen FW. Teach the teachers: an observational study on mentor traineeship in gynecological laparoscopic surgery. Gynecol Obstet Investig. 2007; 64:1-7. 